\title{
2016年度研修・研修関連施設 指定・更新申請要項
}

2016年 4 月 1 日に指定・更新となる循環器専門医研修施設および研修関連施設（循環器専門医制度 規則第 $11,12,13,14$ 条による)の申請受付・審查を下記の要領で行います.

\section{1. 日程}

記

研修施設, 研修関連施設の指定・更新申請はインターネットを介してWEB にて行います。今回の指 定期間は2016年 4 月 1 日から 2018 年 3 月31日までとなります。 申請を希望する施設は, 本会ホーム ページ「循環器専門医制度」から「循環器専門医研修・研修関連施設の指定・更新審査について」にア クセスして手続きをしてください（10月 1 日(木) 10時より開始)。詳細については本会ホームページの 操作説明をご確認ください.

更新申請のご案内 : 2015年 9 月下旬

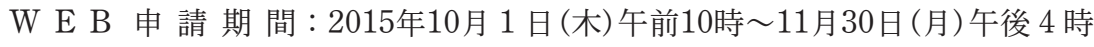

書 類 提 出 期 間: 2015年10月 1 日 (木) 12月 1 日 (火)消印有効

指定・更新結果通知：2016年 3 月中旬

・指定・更新通知は, 施設証の送付をもって代えさせて頂きます．なお，指定不可の場合には，別途 書面にて通知いたします.

・(一社) 日本専門医機構認定の専門医制度の開始時期によっては, 指定期間が短縮されることがあり ます，その場合は必ず事前にご連絡致します．何卒ご了承願います．

\section{2. 施設申請者}

・施設申請者は当該施設常勤の循環器専門医に限ります.

・二重登録を防ぐため，同一施設において，複数の専門医がそれぞれ申請することはできません，

・更新対象施設の施設申請者は既に登録されています。新規に申請手続を行われた専門医は当該施設 の施設申請者として登録されます.

・施設申請に関する全ての連絡（問い合わせ・施設証送付など）について E-mail・郵便などを施設申 請者宛にお送りしますので, ご留意ください.

・施設申請者として登録された専門医は，学会 HPに「代表の循環器専門医」として掲載します.

\section{更新に該当する施設で，施設申請者に変更がある場合は早急にご連絡をお願いいたします.}

専門医制度担当メール：senmoni@j-circ.or.jp

\section{3. 申請資格}

指定を希望する施設は, 次の全てを充足することが必要です (専門医制度規則第13条). 必要に応じ て現地調査を行います。

\section{A. 研修施設}

1）循環器系病床として常時30床以上を有すること. $※ 1 ~$

2) 循環器専門医 2 名以上が常勤し, 指導体制が充分であること.

3）研修カリキュラムに基づく研修が可能な指導体制・設備が整つていること．※2

\section{B. 研修関連施設}
1) 日本循環器学会が指定した研修施設と連係をもつこと.
2) 循環器専門医 1 名以上が常勤すること.
3）指定研修施設と相談のうえ, 研修カリキュラムの一部を受けもつこと. また, 自施設でも基 本的な研修が可能な設備が整つていること. ※2
4）循環器系病床として常時 15 床以上を有すること．※1 
※1 循環器科, 心臟血管外科, 小児循環器科, CCU 含みます。ただし透析病床は含みません.

※2 設備状況の達成目標 $\mathrm{A}$ 項目が全て必要です。また, 達成目標 B 項目についても審査・評価を いたします。なお，専門医を目指す医師の研修のためには，研修カリキュラム達成度評価表 の内容を満たすことが必要です.

指定の循環器研修施設・研修関連施設には, 本学会学術委員会にて実施する「循環器疾患診療の 実態調査※」にもご協力いただくことが更新時の条件となりました (2010年 6 月25日理事会承認). 更新審査において, 申請年を含めて過去 2 回の実態調査に回答が無い場合は, 更新は認められませ ん. ご留意ください.

※循環器診療の質を向上させるための調査であり, 集計データは HPにて公開しています.

\section{4. 申請方法}

【新規申請の施設】

〈新規申請〉指定を希望する施設は, WEB 申請ページから「研修施設」「研修関連施設」いずれかの 申請種別を選択し，直近1年間の施設内状況，設備状況などを入力してください.

【更新対象の施設】

・2016年度更新申請は，2014年 4 月 1 日付けで研修施設・研修関連施設として指定・更新された施 設が対象となります。

・申請手続は学会に登録されている施設申請者のみが行えます。施設情報は施設申請者の WEB ペー ジに連結していますので，施設申請者の ID・PW でログインし下記いずれかの申請手続をしてく ださい．登録されている施設申請者以外が申請すると〈新規申請〉となり，更新・鞍替・辞退申請 としての登録ができません。

〈更新申請〉更新を希望する施設は, WEB 申請ページから「更新申請」を選択し, 直近 1 年間の施 設内状況，設備状況などを入力してください.

〈鞍替申請〉「研修施設 $\rightarrow$ 研修関連施設」または「研修関連施設 $\rightarrow$ 研修施設」への指定資格の変更を希 望する施設は, WEB 申請ページから「鞍替申請」を選択し, 直近 1 年間の施設内状況, 設備状況などを入力してください.

〈辞退申請〉 WEB 申請ページから「辞退申請」を選択し, 辞退事由を入力してください.

上記，申請期間内にいずれかの申請がない場合及び辞退申請をした場合は，資格の喪失となりま す.（専門医制度規則第14条(1)（2）による）

\section{5. 書類提出}

WEB 申請ページから申請後, 申請書を印刷し署名・捺印のうえ提出してください. なお, 研修関連 施設として申請する場合は，連係する研修施設の責任者印も必要となります．WEB 申請ぺージへの入 力だけでは申請は受理されませんので, 必ず書類を送付してください.

- 必要書類 :

〈新規申請〉〈更新申請〉〈鞍替え申請〉：研修施設または研修関連施設 指定・更新申請書（3 枚） 〈辞退申請〉：辞退申請書（1 枚）

- 提出先 : 日本循環器学会 専門医制度委員会

干100-0011 東京都千代田区内幸町 1-1-1 帝国ホテルタワー $18 \mathrm{~F}$ 


\section{6. 情報公開}

研修施設・研修関連施設につきましては，以下の情報を学会 HPにて公開しますので，ご了承下さ い.

・施設指定区分，施設番号，施設名称，所在地，電話番号，FAX 番号

・施設長氏名, 施設申請者 
一般社団法人日本循環器学会認定循環器専門医

研修・研修関連施設 指定・更新申請書

(一社) 日本循環器学会

専門医制度委員会 委員長 殿

(一社) 日本循環器学会認定循環器専門医研修・研修関連施設の指定・更新について, 下記のとおり申請 します.

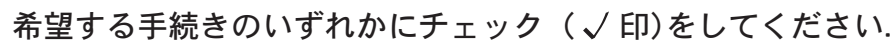

口「研修施設」として指定審査を希望します。（口研修関連施設からの鞍替え申請です）

口「研修関連施設」として指定審査を希望します。(口研修施設からの鞍替え申請です)

\begin{tabular}{|c|c|c|c|}
\hline フ リ ガ & & & \\
\hline 申 請 施 設 名 称 & & & \\
\hline \multirow{3}{*}{ 施設 住 所 ほ か } & \multicolumn{3}{|l|}{$\bar{T}$} \\
\hline & 代表 TEL & 内線番号 & \\
\hline & 部科 TEL & 部科 FAX & \\
\hline 施 設 長（病 院 長） & 役職名 & 氏名 & \\
\hline $\begin{array}{l}\text { 申 請 者 } \\
\text { （循環器専門医代表者） }\end{array}$ & 部科名 & 氏名 & 印 \\
\hline 申請者 E-mail アドレス & & & \\
\hline
\end{tabular}

【常勤循環器専門医：合計

名】研修施設は, (1)に上記申請者, (2)に他 1 名の常勤専門医の情報を 記入すること. 研修関連施設は, (1)に上記申請者を記入すること.

\begin{tabular}{|l|r|r|r|r|}
\hline \multicolumn{1}{|c|}{ 氏 名 } & 部科名 & 会員番号 & 専門医番号 & 備 考 \\
\hline (1) & & & & \\
& & & & \\
\hline (2) & 科 & & \\
& & & & \\
\hline
\end{tabular}

【日本循環器学会会員：合計

名】施設に所属する会員数（上記専門医を含む）を記入すること.

【研修施設の責任者記名欄*】研修関連施設の指定を希望する時のみ記入を依頼すること.

上記申請施設と連係して, 循環器専門医研修カリキュラムに基づく研修を行っていることを証明します。

循環器専門医研修施設 施設名称

施設番号

)

循環器専門医研修施設

責任者 氏名＊

役職名

*責任者記名欄は，研修施設の責任者 (理事長・病院長・教授・部長等)が記名・捺印すること. 
【施設内情報】 20 年 $\quad$ 月 $\quad$ 日〜 20 年 月 $\quad$ 日までの 1 年間の状況を申請します.

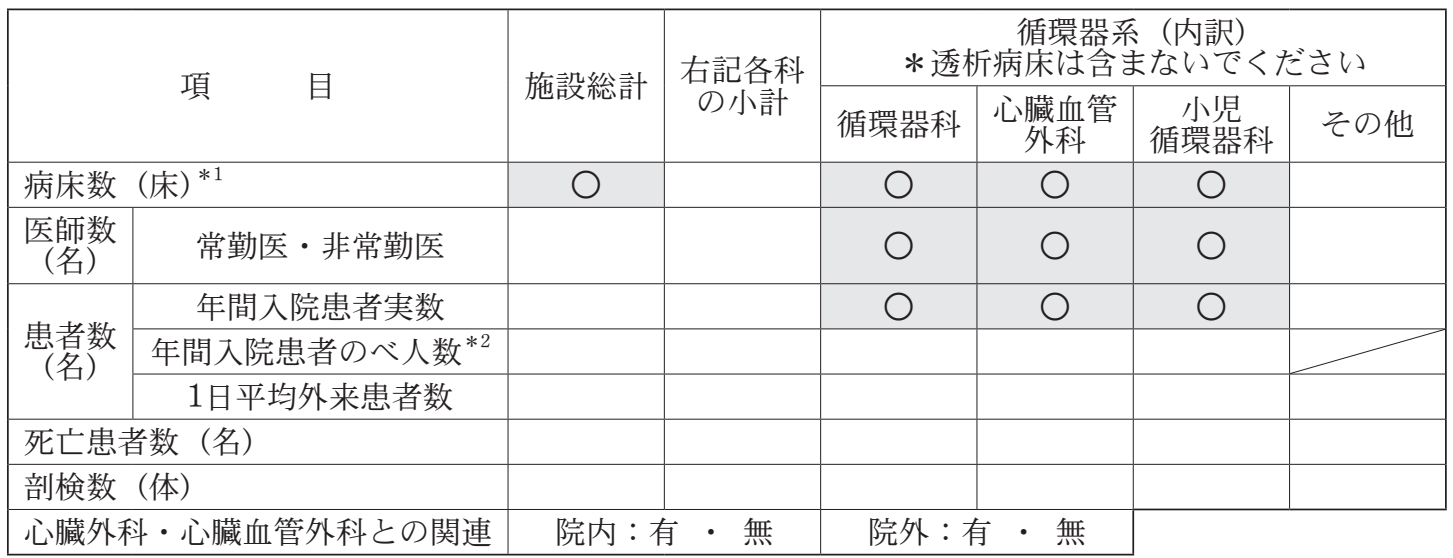

${ }^{* 1}$ 固定の病床数が決められていない場合は, 実績数から算出すること.

算出例) 年間入院患者実数 $\times 1$ 人あたりの年間入院日数 $\div 360$ 日

*2 年間入院患者ののべ人数を記入すること. 算出例 $)$ 年間入院患者実数 $\times 1$ 人あたりの年間入院日数

\section{【設備状況調査表】}

日本循環器学会認定循環器専門医研修カリキュラムに基づく研修が施行されているかをチエックする 項目です.

指定/指定更新には，研修カリキュラムの達成目標 A 項目が全て必要です。

・設備状況欄には，設備が有る場合は○印を，無い場合は×印を記入すること.

・検査および治療件数は, 循環器系で施行した件数を記入すること. 斜線の部分は記入不要です.

\begin{tabular}{|c|c|c|c|}
\hline $\begin{array}{c}\text { 検査項目 } \\
\text { （）内は研修カリキュラム成目標レベル }\end{array}$ & $\begin{array}{c}\text { 設備状況 } \\
\text { 有 : } \bigcirc \\
\text { 無 : }\end{array}$ & $\begin{array}{l}\text { 検査件数 } \\
\text { (年 間) }\end{array}$ & 備 \\
\hline \multicolumn{4}{|l|}{ 胸部 X 線単純撮影 $(\mathrm{A})$} \\
\hline 心血管造影１）左室造影（B） & & O & \multirow{16}{*}{$\begin{array}{l}\text { ※昨年度の申請より, } \\
\text { 更新施設でかつ循環器 } \\
\text { 疾患診療実態調査へ } \\
\text { デー夕を入力頂いてい } \\
\text { る施設においてい, } \\
\text { 【施設内情報】と【設 } \\
\text { 備状況調査表】の項目 } \\
\text { (○印が入つている項 } \\
\text { 目)に診療実態調查で } \\
\text { 入力されたデータが反 } \\
\text { 映されています. } \\
\text { 上記項目への入力は不 } \\
\text { 要ですので, その他の } \\
\text { 空欄となつている項目 } \\
\text { へ入力をお願い致し } \\
\text { ます. }\end{array}$} \\
\hline 2) 大動脈造影 $(\mathrm{B})$ & & $\mathrm{O}$ & \\
\hline 3) 冠動脈造影（B） & & $\bigcirc$ & \\
\hline 4) 右心系造影 (B) & & $\mathrm{O}$ & \\
\hline X 線 CT (computerized tomography) (B) & & 2 & \\
\hline 標準12誘導心電図 $(A)$ & & 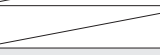 & \\
\hline 運動負荷心電図 (A) & & $\bigcirc$ & \\
\hline Holter 心電図 $(\mathrm{A})$ & & $\mathrm{O}$ & \\
\hline 心臓電気生理学的検査 (B) & & O & \\
\hline \multicolumn{3}{|l|}{ 末梢動脈検査 $(\mathrm{ABI})(\mathrm{B})$} & \\
\hline 経胸壁心エコー図 (A) & & $\mathrm{O}$ & \\
\hline 経食道心エコー図（B) & & O & \\
\hline 頸動脈エコー図（B） & & 2 & \\
\hline Swan-Ganz カテーテル検査 (A) & & 2 & \\
\hline 心 (左・右) カテーテル検査 $(\mathrm{B})$ & & 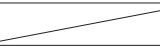 & \\
\hline 心拍出量 (B) & & 2 & \\
\hline 動・静脈圧 (モニ夕) $(\mathrm{A})$ & & 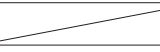 & $\begin{array}{l}\text { 目)に診療実態調査で } \\
\text { 入力されたデータが } \\
\text { 映されています. } \\
\text { 上記項目への入力は不 } \\
\text { 要ですので, その他の } \\
\text { 空欄となっている項目 } \\
\text { へ入力をお願い致し } \\
\text { ます. }\end{array}$ \\
\hline \multicolumn{4}{|l|}{ 心筋シンチ (血流・代謝) $(\mathrm{B})$} \\
\hline 心藏 MRI (magnetic resonance imaging ) (B) & & O & \\
\hline 24時間血圧測定（B） & & & \\
\hline
\end{tabular}




\begin{tabular}{|c|c|c|c|c|}
\hline $\begin{array}{c}\text { 検査項目 } \\
\text { （）内は研修カリキュラム達成目標レベル }\end{array}$ & $\begin{array}{c}\text { 設備状況 } \\
\text { 有: } \bigcirc \\
\text { 無 }: \times\end{array}$ & $\begin{array}{l}\text { 治療件数 } \\
\text { (年 間) }\end{array}$ & 備 & 考 \\
\hline 救急蘇生法 $(\mathrm{BLS} \cdot \mathrm{ALS})(\mathrm{A})$ & & 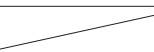 & & \\
\hline 一時的心臓ペーシング (体外的も含めて) (A) & & 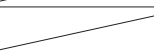 & & \\
\hline 大動脈内バルーンパンピング (IABP) (B) & & O & & \\
\hline ペースメーカ植込み (B) & & O & & \\
\hline 植込み型除細動器 (ICD) (C) & & 0 & & \\
\hline 経皮的冠インターベンション (PCI) (B) & & O & & \\
\hline 血液透析・腹膜透析 $(B)$ & & & & \\
\hline カテーテルアブレーション (C) & & O & & \\
\hline
\end{tabular}

\begin{tabular}{|c|c|c|c|c|c|}
\hline \multicolumn{2}{|c|}{$\begin{array}{c}\text { 検査項目 } \\
\text { （）内は研修カリキュラム成目標レベル }\end{array}$} & \multirow[t]{2}{*}{$\begin{array}{c}\text { 設備状況 } \\
\text { 有 }: \bigcirc \\
\text { 無 }: \times \\
\end{array}$} & \multirow[t]{2}{*}{$\begin{array}{l}\text { 開催回数 } \\
\text { (年 間) }\end{array}$} & \multirow[t]{2}{*}{ 備 } & \multirow[t]{2}{*}{ 考 } \\
\hline \multirow{2}{*}{$\begin{array}{l}\text { 医療倫理 } \\
(\mathrm{A})\end{array}$} & 医療安全推進室・リスクマネージメ & & & & \\
\hline & 医療倫理・安全に関する講習会 & & & & \\
\hline \multicolumn{6}{|c|}{ その他医療倫理・医療安全に関する活動がありましたら記入してください. } \\
\hline
\end{tabular}

\section{【その他調査事項】}

\begin{tabular}{|c|c|c|c|c|c|c|c|}
\hline 病理医数 & 常勤 & 名・無 & ／非常勤 & 名 & \multirow{2}{*}{$\begin{array}{c}\text { 購読循環器 } \\
\text { 関連誌 } \\
\end{array}$} & 国内雑誌数 & \multirow{2}{*}{$\begin{array}{l}\text { 冊 } \\
\text { 冊 }\end{array}$} \\
\hline 救急施設 & \multicolumn{2}{|c|}{ 有 . 無 } & $/ \mathrm{CCU}$ 病床数 & 床 & & 国外雑誌数 & \\
\hline \multicolumn{2}{|l|}{ セミナー } & 有 - 無 & ／月平均開催数 & 回 & 動物実験 & 有 - 無 & \\
\hline \multicolumn{2}{|l|}{ 抄読会 } & 有 - 無 & /月平均開催数 & 回 & & & \\
\hline \multicolumn{2}{|c|}{ カンファレンス } & 有 - 無 & /月平均開催数 & 回 & & & \\
\hline \multicolumn{8}{|c|}{ その他教育活動を具体的に記入してください. } \\
\hline
\end{tabular}

\section{【責任者署名欄 $* 】$}

上記の申請書記載内容に䛊りがないことを証明します。

\begin{tabular}{|l|l|}
\hline 役職名 & 責任者署名 \\
& \\
& \\
\hline
\end{tabular}

*責任者署名欄は記載内容の証明者として, 申請施設の責任者 (理事長・病院長・教授・部長等)が 署名・捺印すること. ゴム印不可. 


\section{日本循環器学会指定 循環器専門医研修施設}

\section{北海道地区}

《北海道》

北海道大学病院

札幌医科大学附属病院

旭川医科大学病院

函館中央病院

市立室蘭総合病院

医療法人王子総合病院

社会医療法人延山会 北成病院

帯広厚生病院

市立釧路総合病院

函館五稜郭病院

札幌循環器病院

NTT 東日本札幌病院

心臟血管センター北海道大野病院

カレスサッポロ北光記念病院

市立旭川病院

旭川赤十字病院

手稻渓仁会病院

製鉄記念室蘭病院

医療法人社団北海道恵愛会札幌南一条病院

市立函館病院

国立病院機構 函館病院

市立札幌病院

医療法人北晨会恵夕野病院

砂川市立病院

地域医療機能推進機構 札幌北辰病院

JR 札幌病院

時計台記念病院

カレスアライアンス天使病院

札幌東徳洲会病院

北海道社会事業協会 帯広病院

岩見沢市立総合病院

北見赤十字病院

$\mathrm{JA}$ 北海道厚生連遠軽厚生病院

江別市立病院

$\mathrm{JA}$ 北海道厚生連 網走厚生病院

北海道病院 心臟血管センター

北斗病院

勤医協中央病院

苫小牧市立病院

厚生連総合病院札幌厚生病院

市立根室病院

渓和会江別病院

独立行政法人国立病院機構 帯広病院

新札幌循環器病院

社会医療法人 禎心会病院

医) 社団 SSJ 札幌整形循環器病院

小樽市立病院

札幌心臟血管クリニック

釧路孝仁会記念病院

札幌白石記念病院

北海道医療センター

名寄市立総合病院

北海道社会事業協会小樽病院

旭川厚生病院

KKR 札幌医療センター

北海道循環器病院

北海道中央労災病院

総合病院伊達赤十字病院
東 北地区

《青森県》

弘前大学医学部附属病院

青森県立中央病院

八戸市立市民病院

むつ総合病院

青森市民病院

つがる西北五広域連合つがる総合病院 《岩手県》

岩手医大附属病院・循環器医療センター 岩手県立中央病院

岩手県立胆沢病院

岩手県立磐井病院

岩手県立中部病院

岩手県立大船渡病院

岩手県立二戸病院

盛岡赤十字病院

《宮城県》

東北大学病院

東北労災病院

仙台循環器病センター

公益財団法人 仙台市医療センター仙台オープン病院 財団法人宮城厚生協会坂総合病院

仙台市立病院

仙台徳洲会病院

独立行政法人国立病院機構 仙台医療センター 東北薬科大学病院

(一財) 厚生会 仙台厚生病院

気仙沼市立病院

大崎市民病院

$\mathrm{JCHO}$ 仙台南病院

宫城県立循環器・呼吸器病センター みやぎ県南中核病院

石巻赤十字病院

《秋田県》

秋田大学医学部附属病院

平鹿総合病院

中通総合病院

秋田厚生医療センター

秋田赤十字病院

大曲厚生医療センター

市立秋田総合病院

《山形県》

山形大学医学部附属病院

山形市立病院済生館

山形県立中央病院

米沢市立病院

鶴岡市立荘内病院

山形県立新庄病院

日本海総合病院

北村山公立病院

公立置賜総合病院

《福島県》

福島県立医科大学医学部附属病院

公益財団法人星総合病院

いわき市立総合磐城共立病院

会津中央病院

財団法人竹田綜合病院

福島労災病院

(一財) 太田綜合病院附属太田西八内病院

(財)大原綜合病院附属大原医療センター
総合南東北病院

社会医療法人福島厚生会 福島第一病院 福島県立医科大学 会津医療センター 医療生協わたり病院

綜合病院 福島赤十字病院

白河厚生総合病院

医療法人平心会須賀川病院

湯浅報恩会寿泉堂綜合病院

\section{関東甲信越地区}

\section{《茨城県》}

筑波大学附属病院

土浦協同病院

東京医科大学茨城医療センター

社会福祉法人水戸済生会総合病院

筑波記念病院

筑波メディカルセンター病院

(株) 日立製作所日立総合病院

国立病院機構 水戸医療センター

総合守谷第一病院

茨城西南医療センター病院

社会医療法人 愛宣会 ひたち医療センター

茨城県立中央病院

日立製作所ひたちなか総合病院

小山記念病院

水戸ブレインハートセンター

(医)社団常仁会牛久愛和総合病院

《栃木県》

獨協医科大学病院

自治医科大学附属病院

杤木県済生会宇都宮病院

足利赤十字病院

うつのみや病院

新小山市民病院

佐野厚生総合病院

獨協医科大学日光医療センター

宇都宮記念病院

国際医療福祉大学病院

国立病院機構栃木医療センター

\section{《群馬県》}

群馬大学医学部附属病院

国立病院機構高崎総合医療センター

群馬県立心臟血管センター

医療法人北関東循環器病院

群馬県済生会前橋病院

公立藤岡総合病院

前橋赤十字病院

群馬中央病院

伊勢崎市民病院

邑楽館林医療事務組合館林厚生病院

医療法人鶴谷会鶴谷病院

富士重工業健康保険組合太田記念病院 《埼玉県》

獨協医科大学越谷病院

埼玉医科大学総合医療センター

防衛医科大学校病院

さいたま赤十字病院

社会医療法人財団 石心会 埼玉石心会病院 自治医科大学附属さいたま医療センター 埼玉医科大学国際医療センター

さいたま市立病院

医療法人社団東光会戸田中央総合病院 
小川赤十字病院

国立病院機構 埼玉病院

深谷赤十字病院

川口市立医療センター

埼玉県済生会栗橋病院

埼玉県立循環器・呼吸器病センター 済生会川口総合病院

川口工業総合病院

越谷市立病院

医療法人社団愛友会上尾中央総合病院

草加市立病院

春日部中央総合病院

彩の国 東大宮メディカルセンター

医療法人社団松弘会 三愛病院

国立病院機構 西埼玉中央病院

埼玉東部循環器病院

秀和総合病院

新座志木中央総合病院

北里大学メディカルセンター

埼玉メディカルセンター

健仁会 益子病院

三鄉中央総合病院

みさと健和病院

イムス富士見総合病院

さいたま市民医療センター

医療法人社団尚篤会赤心堂病院

埼玉協同病院

春日部市立病院

《千葉県》

千葉大学医学部附属病院

帝京大学ちば総合医療センター

船橋市立医療センター

千葉県勤労者医療協会船橋二和病院

医療法人社団保健会谷津保健病院

地域医療機能推進機構 千葉病院

千葉市立海浜病院

東京慈恵会医科大学附属柏病院

総合病院国保旭中央病院

労働福祉事業団千葉労災病院

千葉県循環器病センター

亀田総合病院

千葉西総合病院

国保松戸市立病院

新東京病院

順天堂大学医学部附属浦安病院

東邦大学医療センター佐倉病院

日本医科大学千葉北総病院

医療法人沖縄徳洲会千葉徳洲会病院

(医財) 東京勤労者医療会東葛病院

千葉市立青葉病院

君津中央病院

東京歯科大学市川総合病院

医療法人財団明理会 新松戸中央総合病院

創進会夕つわ台総合病院

東京ベイ・浦安市川医療センター

千葉県済生会習志野病院

医療法人社団誠馨会千葉中央メディカルセンター 成田赤十字病院

小張総合病院・小張総合クリニック

東京女子医科大学八千代医療センター

島田総合病院

鎌ヶ谷総合病院

おおたかの森病院

千葉県救急医療センター

国立病院機構 千葉医療センター 柏市立柏病院

《東京都》

東京大学医学部附属病院

東京医科歯科大学医学部附属病院
東京慈恵会医科大学附属病院

東京慈恵会医科大学葛飾医療センター

日本医科大学付属病院

日本医科大学多摩永山病院

順天堂大学医学部附属順天堂医院

慶應義塾大学病院

東京女子医科大学病院

東京女子医科大学東医療センター

東京医科大学病院

東京医科大学八王子医療センター 昭和大学病院

東邦大学医療センター大橋病院

東邦大学医療センター大森病院

日本大学医学部附属板橋病院

日本大学病院

帝京大学医学部附属病院

杏林大学医学部付属病院

三井記念病院

東京警察病院

東京违信病院

国家公務員共済組合連合会虎の門病院

心臟血管研究所付属病院

東京高輪病院

東京都済生会中央病院

NTT 東日本関東病院

東京都立広尾病院

棉原記念病院

独立行政法人国立病院機構 東京医療センター 東京共済病院

公立学校共済組合関東中央病院

国立国際医療研究センター

JCHO 東京新宿メディカルセンター

東京都健康長寿医療センター

武蔵野赤十字病院

総合病院立川相互病院

聖路加国際病院

JR 東京総合病院

公立昭和病院

東京慈恵会医科大学附属第三病院

財団法人日産厚生会玉川病院

豊島病院

総合病院厚生中央病院

自衛隊中央病院

北里研究所病院

日本赤十字社東京都支部大森赤十字病院

葛西昌医会病院

東京山手メディカルセンター

東京都保健医療公社東部地域病院

(財) 東京都保健医療公社荏原病院

日本赤十字社医療セン夕ー

東京都立多摩総合医療センター

多摩北部医療センター

多摩南部地域病院

同愛記念病院

医療法人社団東光会西東京中央総合病院

社会福祉法人仁生社江戸川病院

東芝病院

国家公務員共済組合連合会三宿病院

河北総合病院

綾瀬循環器病院

町田市民病院

国立病院機構 東京病院

医療法人社団順江会 江東病院

東京都立大塚病院

日野市立病院

東海大学医学部付属八王子病院

公立福生病院

(医)社団松和会 池上総合病院ハートセンター

東京都立墨東病院
東京臨海病院

医療法人社団苑田会 苑田第一病院

永寿総合病院

大崎病院東京ハートセンター

練馬病院

東京北医療センター

東京西徳洲会病院

国際医療福祉大学三田病院

博鳳会敬愛病院

イムス葛飾ハートセンター

浮間中央病院

府中恵仁会病院

西新井ハートセンター病院

練馬光が丘病院

東京蒲田病院

国家公務員共済組合連合会立川病院

立正佼成会附属佼成病院

医療法人社団明芳会板橋中央総合病院 公立阿伎留医療センター

大久保病院

医療法人財団荻窪病院

青梅市立総合病院

社会医療法人財団大和会東大和病院

独立行政法人国立病院機構 災害医療セン夕ー

博慈会記念総合病院

《神奈川県》

聖マリアンナ医科大学病院

聖マリアンナ医科大学横浜市西部病院

横浜市立大学附属病院

昭和大学藤が丘病院

北里大学病院

東海大学医学部付属病院

関東労災病院

国家公務員共済組合連合会横浜栄共済病院

藤沢市民病院

神奈川県立循環器呼吸器病センター

国立病院機構 横浜医療センター

湘南鎌倉総合病院

横須賀市立市民病院

けいゆう病院

(労) 横浜労災病院

横浜市立みなと赤十字病院

横浜南共済病院

横須賀共済病院

国際親善総合病院

茅ケ崎市立病院

社会医療法人財団石心会 川崎幸病院

相模原協同病院

済生会横浜市南部病院

聖隷福祉事業団聖隷横浜病院

横浜市立市民病院

平塚市民病院

日本鋼管病院

川崎市立川崎病院

横浜市立大学附属市民総合医療センター

川崎南部病院

日本医科大学武蔵小杉病院

厚木市立病院

小田原市立病院

帝京大学医学部附属溝口病院

医療法人邦友会小田原循環器病院

一般社団法人日本厚生団 長津田厚生総合病院

$\mathrm{JCHO}$ 横浜中央病院

イムスグループ 横浜旭中央総合病院

藤沢湘南台病院

聖マリアンナ医科大学東横病院

昭和大学横浜市北部病院循環器センター

総合高津中央病院

横浜総合病院ハートセンター 
葉山ハートセンター

医療法人社団康心会湘南東部総合病院 横浜保土ヶ谷中央病院

大和市立病院

川崎市立多摩病院

済生会横浜市東部病院

海老名総合病院

秦野赤十字病院

大和成和病院

総合新川橋病院

相模野病院

新百合ヶ丘総合病院

医療法人社団総生会 麻生総合病院

川崎市立井田病院

東芝林間病院

横須賀市立うわまち病院

医療法人五星会菊名記念病院

東名厚木病院

国立病院機構 相模原病院

平塚共済病院

《新潟県》

新潟大学医歯学総合病院

長岡赤十字病院

新潟医療センター

新潟市民病院

立川綜合病院

済生会新潟第二病院

新潟県立新発田病院

新潟県立中央病院

信楽園病院

木戸病院

新潟県厚生連長岡中央綜合病院

《山梨県》

山梨大学医学部附属病院

山梨県立中央病院

(社) 山梨勤労者医療協会甲府共立病院

甲府城南病院

山梨赤十字病院

財団法人山梨厚生会山梨厚生病院

《長野県》

信州大学医学部附属病院

長野赤十字病院

長野県厚生連北信総合病院

松本協立病院

安曇野赤十字病院

長野松代総合病院

信州上田医療センター

慈泉会相澤病院

飯田市立病院

諏訪中央病院

市立岡谷病院

健和会病院

長野医療生活協同組合長野中央病院

JA 長野厚生連佐久総合病院佐久医療セン夕ー

長野県厚生連篠ノ井総合病院

諏訪赤十字病院

長野市民病院

\section{東 海地 区}

《岐阜県》

岐阜大学医学部附属病院

岐阜県総合医療センター

岐阜市民病院

独立行政法人国立病院機構 長良医療セン夕ー

羽島市民病院

大垣市民病院

松波総合病院

岐阜赤十字病院

岐阜県立多治見病院
岐阜県厚生連 揖斐厚生病院 岐阜県厚生連 岐北厚生病院 木沢記念病院

朝日大学歯学部附属村上記念病院 公立学校共済組合東海中央病院

JA 岐攴厚生連 久美愛厚生病院

岐阜八ートセンター

JA 岐阜厚生連中濃厚生病院

可児とうのう病院

《静岡県》

浜松医科大学医学部附属病院

総合病院聖隷浜松病院

国立病院機構 静岡医療センター

静岡県立総合病院

静岡済生会総合病院

静岡市立静岡病院

市立島田市民病院

聖隷三方原病院

中東遠総合医療センター

磐田市立総合病院

藤枝市立総合病院

浜松労災病院

浜松医療センター

順天堂大学医学部附属静岡病院

焼津市立総合病院

岡村記念病院

富士宮市立病院

富士市立中央病院

菊川市立総合病院

社団法人有隣厚生会富士病院

国際医療福祉大学熱海病院

静岡県立静岡がんセンター

静岡徳洲会病院

市立湖西病院

静岡赤十字病院

JA 静岡厚生連 遠州病院

浜松赤十字病院

《愛知県》

名古屋大学医学部附属病院

名古屋市立大学病院

藤田保健衛生大学病院

愛知医科大学病院

豊橋市民病院

安城更生病院

刈谷豊田総合病院

名古屋鉄道健康保険組合名鉄病院

独立行政法人地域医療機能推進機構中京病院

国立病院機構 名古屋医療セン夕一

名城病院

名古屋第二赤十字病院

愛知県厚生連豊田厚生病院

小牧市民病院

名古屋第一赤十字病院

名古屋掖済会病院

中部万うさい病院

協立総合病院

春日井市民病院

愛知県厚生連 渥美病院

西尾市民病院

卜ヨ夕記念病院

半田市立半田病院

一宮市立市民病院

社会医療法人宏潤会 大同病院

総合病院南生協病院

愛知県厚生連 江南厚生病院

公立陶生病院

愛知厚生連 海南病院

蒲郡市民病院

岡崎市民病院
旭労災病院

名古屋市立東部医療センター

津島市民病院

名古屋記念病院

名古屋徳洲会総合病院

医療法人澄心会豊橋ハートセンター 藤田保健衛生大学坂文種報徳會病院 医療法人偕行会 名古屋共立病院 愛知県厚生連 尾西病院

総合犬山中央病院

名古屋ハートセンター

一宮西病院

稲沢市民病院

さくら総合病院

総合大雄会病院

豊川市民病院

碧南市民病院

《三重県》

三重大学医学部附属病院

三重県立総合医療センター

桑名東医療セン夕一

三重県厚生連鈴鹿中央総合病院

医療法人永井病院

三重県厚生連松阪中央総合病院

済生会松阪総合病院

医療法人同心会遠山病院

伊勢赤十字病院

市立四日市病院

松阪市民病院

国立病院機構 三重中央医療センター

桑名南医療センター

名張市立病院

社会医療法人 畿内会 岡波総合病院

四日市羽津医療セン夕ー

三重ハートセンター

北陸 地 区

《富山県》

富山大学附属病院

富山市立富山市民病院

高岡市民病院

富山県立中央病院

富山赤十字病院

厚生連高岡病院

黒部市民病院

市立研波総合病院

金沢医科大学水見市民病院

富山県済生会富山病院

射水市民病院

富山県済生会高岡病院

《石川県》

金沢大学附属病院

金沢医科大学病院

石川県立中央病院

心臟血管センター金沢循環器病院

公立能登総合病院

独立行政法人国立病院機構 金沢医療センター

国民健康保険小松市民病院

金沢市立病院

公立松任石川中央病院

やわたメディカルセンター

《福井県》

福井大学医学部附属病院

福井県立病院

福井循環器病院

福井県済生会病院

市立敦賀病院

福井赤十字病院

財団医療法人 中村病院 
福井厚生病院

福井総合病院

\section{近 畿 地 区}

《滋賀県》

滋賀医科大学附属病院

大津赤十字病院

彦根市立病院

滋賀県立成人病センター

長浜赤十字病院

大津市民病院

済生会滋賀県病院

近江八幡市立総合医療センター

市立長浜病院

地域医療機能推進機構 滋賀病院

医療法人社団昴会湖東記念病院

草津総合病院

公立甲賀病院

医療法人弘英会琵琶湖大橋病院

《京都府》

京都大学医学部附属病院

京都府立医科大学附属病院

京都第二赤十字病院

西陣病院

京都第一赤十字病院

三菱京都病院

京都鞍馬口医療センター

京都医療センター

医療法人財団康生会武田病院

医療法人医仁会武田総合病院

洛和会音羽病院

京都桂病院

舞鶴共済病院

京都市立病院

第二岡本総合病院

綾部市立病院

公立南丹病院

医療法人啓信会京都きづ川病院

洛和会丸太町病院

京都府立医科大学附属北部医療センター

独立行政法人国立病院機構 舞鶴医療センター

京都山城総合医療センター

医療法人社団蘇生会蘇生会総合病院

京丹後市立久美浜病院

市立福知山市民病院

田辺中央病院

宇治徳洲会病院

公益社団法人 京都保健会京都民医連中央病院

\section{《大阪府》}

大阪大学医学部附属病院

大阪市立大学医学部附属病院

大阪医科大学附属病院

関西医科大学附属滝井病院

近畿大学医学部附属病院

国立循環器病研究センター

大阪府済生会中津病院

(公財) 田附興風会医学研究所北野病院

住友病院

桜橋渡辺病院

大阪府立成人病センター

大阪鉄道病院

大阪府立急性期・総合医療センター

大阪府三島救命救急センター

松下記念病院

八尾市立病院

医療法人宝生会 PL 病院

独立行政法人国立病院機構 大阪南医療セン夕社会医療法人同仁会 耳原総合病院

大阪労災病院
大阪回生病院

淀川キリス卜教病院

独立行政法人国立病院機構 大阪医療セン夕ー

大阪赤十字病院

大阪警察病院

（公財）日本生命済生会付属日生病院

関西電力病院

地域医療機能推進機構 大阪病院

大阪暁明館病院

社会医療法人愛仁会千船病院

医療法人河内友紘会河内総合病院

堺市立総合医療センター

清恵会病院

社会医療法人ペガサス馬場記念病院

医療法人生長会ベルランド総合病院

国家公務員共済組合連合会 大手前病院

大阪みなと中央病院

南大阪病院

医療法人仙養会北摄総合病院

高槻赤十字病院

若草第一病院

和泉市立病院

医療法人愛仁会高槻病院

星ヶ丘医療センター

市立ひらかた病院

東大阪市立総合病院

医真会八尾総合病院

市立柏原病院

市立岸和田市民病院

大阪市立総合医療センター

大阪府済生会野江病院

多根総合病院

大阪府済生会千里病院

市立豊中病院

医療法人生長会府中病院

りんくう総合医療センター

医療法人育和会育和会記念病院

大阪府済生会泉尾病院

医療法人医誠会医誠会病院

NTT 西日本大阪病院

枚方公済病院

医療法人 春秋会城山病院

医療法人藤井会石切生喜病院

済生会吹田病院

医療法人貴医会貴島中央病院

富永病院

祐生会みどりヶ丘病院

済生会富田林病院

医療法人橘会東住吉森本病院

医療法人徳洲会岸和田徳洲会病院

大阪掖済会病院

市立吹田市民病院

大阪府済生会茨木病院

医療法人徳洲会 野崎徳洲会病院

守口生野記念病院

高石藤井心臓血管病院

摄南総合病院

加納総合病院

医療法人朋愛会朋愛病院

社会医療法人大道会 森之宮病院

吹田徳洲会病院

医療法人マックシール巽病院

市立池田病院

浅香山病院

関西医科大学附属枚方病院

《兵庫県》

神戸大学医学部附属病院

兵庫医科大学病院

神戸掖済会病院
済生会兵庫県病院

労働者健康福祉機構 神戸労災病院

社会保険神戸中央病院

神戸百年記念病院

国立病院機構 神戸医療センター

兵庫県立淡路医療センター

兵庫県立尼崎総合医療センター

公立学校共済組合近畿中央病院

宝塚市立病院

兵庫県立姫路循環器病センター

独立行政法人国立病院機構 姫路医療セン夕ー

医療法人社団明石医療センター

北播磨総合医療センター

市立加西病院

神鋼記念病院

三菱神戸病院

関西労災病院

三田市民病院

兵庫県立柏原病院

社会医療法人製鉄記念広畑病院

加古川東市民病院

赤穂市民病院

医療法人浩生会舞子台病院

神戸市立医療センター中央市民病院

医療法人明和病院

市立伊丹病院

一般財団法人甲南会 六甲アイランド甲南病院

公立豊岡病院組合立豊岡病院

(財) 神戸市地域医療振興財団西神戸医療セン夕ー

医療法人川崎病院

公立八鹿病院

医療法人協和会協立病院

明石市立市民病院

西脇市立西脇病院

医療法人財団済美会 昭和病院

東宝塚さとう病院

市立川西病院

神戸赤十字病院

ツカザキ病院

尼崎中央病院

西宮渡辺心臓・血管センター

はくほう会セントラル病院

晋真会 ベリタス病院

医療法人社団さくら会 高橋病院

兵庫県立こども病院

市立芦屋病院

みごり病院

姫路赤十字病院

兵庫県立西宮病院

兵庫県立加古川医療センター

《奈良県》

奈良県立医科大学附属病院

市立奈良病院

奈良県総合医療センター

宇陀市立病院

奈良県西和医療センター

天理よろづ相談所病院

医療法人康仁会西の京病院

社会医療法人高清会 高井病院

近畿大学医学部奈良病院

医療法人新生会 高の原中央病院 《和歌山県》

和歌山県立医科大学附属病院

日本赤十字社和歌山医療センター

紀南病院

有田市立病院

南和歌山医療センター

誠佑記念病院

公立那賀病院 
和歌山労災病院 済生会和歌山病院

橋本市民病院

\section{中 国 地 区}

\section{《鳥取県》}

鳥取大学医学部附属病院

鳥取県立厚生病院

鳥取市立病院

山陰労災病院

鳥取赤十字病院

鳥取県立中央病院

《島根県》

島根大学医学部附属病院

島根県立中央病院

松江赤十字病院

松江市立病院

総合病院松江生協病院

島根県済生会江津総合病院

《岡山県》

岡山大学病院

川崎医科大学附属病院

心臓病セン夕一榊原病院

岡山赤十字病院

独立行政法人国立病院機構 岡山医療セン夕ー

財団法人倉敷中央病院

津山中央病院

総合病院岡山協立病院

川崎医科大学附属川崎病院

岡山労災病院

岡山済生会総合病院

岡山市立市民病院

《広島県》

広島大学病院

国立病院機構 福山医療センター

福山市民病院

国家公務員共済組合連吳共済病院

県立広島病院

吳医療センター

中国労災病院

JA 広島総合病院

医療法人あかね会土谷総合病院

広島市立安佐市民病院

福山循環器病院

広島赤十字・原爆病院

済生会広島病院

広島県厚生農業協同組合連合会尾道総合病院

広島鉄道病院

中国電力株式会社中電病院

広島市立広島市民病院

社会医療法人里仁会 興生総合病院

市立三次中央病院

国立病院機構 東広島医療センター

マツダ株式会社マツダ病院

《山口県》

山口大学医学部附属病院

山口県立総合医療センター

下関市立市民病院

山口県済生会下関総合病院

国立病院機構 岩国医療センター

関門医療センター

済生会山口総合病院

医療法人社団宇部興産中央病院

社会保険徳山中央病院

神徳会三田尻病院

医療法人社団成蹊会岡田病院

下関医療センター

山口厚生農業協同組合連合会 周東総合病院 萩市民病院
山口労災病院

綜合病院山口赤十字病院

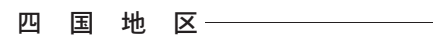

\section{《徳島県》}

徳島大学病院

国立病院機構 東徳島医療センター

徳島赤十字病院

徳島県立中央病院

吉野川医療センター

川島会 川島病院

徳島県立三好病院

徳島市民病院

《香川県》

香川大学医学部附属病院

高松赤十字病院

三豊総合病院

香川県立中央病院

香川県立白鳥病院

高松市民病院

香川労災病院

総合病院坂出市立病院

医療法人財団博仁会 キナシ大林病院

国家公務員共済組合連合会高松病院

香川県済生会病院

国立病院機構 高松医療センター

屋島総合病院

《愛媛県》

愛媛大学医学部附属病院

愛媛県立中央病院

松山赤十字病院

独立行政法人国立病院機構 愛媛医療センター 愛媛県立新居浜病院

愛媛県立今治病院

喜多医師会病院

市立宇和島病院

市立八幡浜総合病院

西条中央病院

済生会今治病院

済生会西条病院

愛媛労災病院

松山市民病院

\section{《高知県》}

高知大学医学部附属病院

高知医療センター

近森病院

高知県立幡多けんみん病院

高知赤十字病院

九 州地区

《福岡県》

九州大学病院

福岡大学病院

産業医科大学病院

久留米大学病院

地域医療機能推進機構 九州病院

福岡市立こども病院

国家公務員共済組合連合会浜の町病院

国家公務員共済組合連合会千早病院

福岡市医師会成人病センター

株式会社麻生飯塚病院

社会医療法人天神会新古賀病院

小倉記念病院

福岡県済生会福岡総合病院

雪の聖母会聖マリア病院

医療法人社団誠心会萩原中央病院

原三信病院

独立行政法人国立病院機構 九州医療セン夕一

北九州市立医療センター
医療法人弘恵会ヨコクラ病院

製鉄記念八幡病院

医療法人白十字会白十字病院

久留米大学医学部附属医療センタ一

医療法人親仁会米の山病院

国立病院機構 福岡東医療センター

総合病院千鳥橋病院

福岡赤十字病院

福岡青洲会病院

健和会大手町病院

宗像水光会総合病院

福岡県済生会二日市病院

福岡記念病院

医療法人福西会 福西会病院

社会保険大牟田天領病院

公立学校共済組合九州中央病院

北九州総合病院

福岡和白病院

公立八女総合病院

柳川病院

済生会八幡総合病院

田主丸中央病院

筑後市立病院

福岡山王病院

医療法人社団高邦会高木病院

九州労贸病院

福岡聥信病院

北九州市立八幡病院

医療法人徳洲会福岡徳洲会病院

杉循環器科内科病院

医療法人井上会篠栗病院

《佐賀県》

佐賀大学医学部附属病院

佐賀県医療センター好生館

唐津赤十字病院

国立病院機構 嬉野医療センター

済生会唐津病院

国立病院機構 東佐賀病院

《長崎県》

長崎大学病院

医療法人光晴会病院

長崎みなとメディカルセンター市民病院

日本赤十字社長崎原爆病院

医療法人宏善会諫早記念病院

独立行政法人国立病院機構 長崎医療セン夕一

佐世保市立総合病院

医療法人厚生会 虹が丘病院

大村市民病院心臓血管病センター

長崎記念病院

長崎川棚医療センター

北松中央病院

地域医療機能推進機構 諫早総合病院 済生会長崎病院

社会医療法人財団 白十字会 佐世保 中央病院

《熊本県》

熊本大学医学部附属病院

済生会熊本病院

熊本中央病院

熊本赤十字病院

公立玉名中央病院

熊本市立熊本市民病院

国立病院機構熊本医療センター

人吉医療センター

医療法人社団寿量会熊本機能病院

医療法人杉村会 杉村病院

地域医療機能推進機構 熊本総合病院 天草郡市医師会立天草地域医療センター (労) 熊本労災病院 


\section{《大分県》}

大分大学医学部附属病院 新別府病院

九州大学病院別府病院

国立病院機構 別府医療センター 医療法人愛寿会 大分循環器病院 大分医療センター

大分県厚生連鶴見病院

大分赤十字病院

社会医療法人敬和会 大分岡病院

大分市医師会立 アルメイダ病院

大分中村病院

大分県立病院

《宮崎県》

宮崎大学医学部附属病院

藤元中央病院
宫崎市郡医師会病院

社団法人藤元メディカルシステム 藤元総合病院 宮崎江南病院

都城市郡医師会病院

宮崎県立延岡病院

県立宫崎病院

《鹿児島県》

鹿児島大学病院

国立病院機構 鹿児島医療センター

医療法人天陽会中央病院

総合病院鹿児島生協病院

鹿児島市医師会病院

鹿児島市立病院

国立病院機構 指宿医療センター

《沖縄県》

琉球大学医学部附属病院
沖縄協同病院

沖縄県立南部医療センター・こども医療センター 那覇市立病院

沖縄県立中部病院

浦添総合病院

社会医療法人敬愛会 中頭病院

中部徳洲会病院

北部地区医師会附属病院

沖縄赤十字病院

医療法人陽心会大道中央病院

豊見城中央病院

大浜第一病院

医療法人博愛会牧港中央病院

ハートライフ病院

研修施設 計 993施設

なお，研修施設一覧は2015年 8 月 1 日現在の情報を元に作成しております

今後名称等に変更が生ずる場合がございますのでご了承願います。また，今後新たに指定・辞退・停止される施設もあり ますので, 詳細や不明な点につきましては (一社) 日本循環器学会事務局へお問い合わせ下さい.

《専門医担当：TEL(03) 5501-0864 FAX(03)5501-9855/e-mail: senmoni@j-circ.or.jp》 


\section{日本循環器学会指定 循環器専門医研修関連施設}

北海道地区

《北海道》

釧路三慈会病院

札幌共立五輪橋病院

滝川市立病院

市立芦別病院

市立千歳市民病院

北海道社会事業協会 富良野病院

旭川リハビリテーション病院

八雲総合病院

社会医療法人延山会 西成病院

イ公不札幌消化器中央総合病院

森山病院

札幌中央病院

社会医療法人母恋 日鋼記念病院

木原循環器科内科医院

北海道立北見病院

留萌市立病院

$$
\text { 東 北地区 }
$$

《青森県》

三沢市立三沢病院

八戸赤十字病院

(財)黎明楖 弘前䐉卒中・リハビリテーションセンター

十和田市立中央病院

《岩手県》

北上済生会病院

岩手県立釜石病院

《宮城県》

東北公済病院

総合南東北病院

仙塩利府病院

仙台赤十字病院

《秋田県》

由利組合総合病院

本荘第一病院

《山形県》

小白川至誠堂病院

公立学校共済組合東北中央病院

済生会山形済生病院

山形県立河北病院

庄内余目病院

鶴岡協立病院

財団法人三友堂病院

《福島県》

済生会福島総合病院

公立相馬総合病院

大原綜合病院

医療法人辰星会枅記念病院

南相馬市立総合病院

敬愛会 福島南循環器科病院

\section{関東甲信越地区}

\section{《茨城県》}

JA とりで総合医療センター

北茨城市民病院

医療法人社団輝峰会東取手病院

誠潤会水戸病院

常陸大宮済生会病院

友愛記念病院

水戸協同病院

古河赤十字病院

財団法人筑波学園病院

国立病院機構 霞ヶ浦医療センター

《栃木県》

医療法人社団全仁会宇都宮中央病院

とちぎメディカルセンター下都賀総合病院
菅間記念病院

芳賀赤十字病院

那須赤十字病院

《群馬県》

公立富岡総合病院

沼田脳神経外科循環器科病院

高瀬クリニック

群馬県立小児医療センター

医療法人社団日高会 日高病院

《埼玉県》

埼玉医療生活協同組合羽生総合病院

社会医療法人社団 新都市医療研究会

[関越]会 関越病院

所沢ハートセンター

岩槻南病院

本庄総合病院

行田総合病院

埼玉医科大学病院

東埼玉総合病院

久喜総合病院

秩父市立病院

(公社) 東松山医師会 東松山医師会病院 《千葉県》

安房地域医療センター

名戸ヶ谷病院

セコメディック病院

柏厚生総合病院

塩田記念病院

東千葉メディカルセンター

《東京都》

東京都教職員互助会三楽病院

東京労災病院

東京女子医科大学附属青山病院

医療法人社団大坪会 東和病院

稲城市立病院

東海大学医学部付属東京病院

社会福祉法人康和会久我山病院

大田病院

順天堂東京江東高齢者医療センター

新山手病院

東京北部病院

明理会中央総合病院

医療法人財団健貢会 総合東京病院

(社) 至誠會第二病院

《神奈川県》

国立病院機構 神奈川病院

医療法人横浜博萌会西横浜国際総合病院

(医)社団一成会たちばな台病院

川崎医療生活協同組合川崎協同病院 湘南藤沢徳洲会病院

昭和大学藤が丘リハビリテーション病院 神奈川県立汐見台病院

東戸塚記念病院

東海大学医学部付属大磯病院

伊勢原協同病院

神奈川県立足柄上病院

相模原中央病院

横浜新都市脳神経外科病院

済生会神奈川県病院

横浜新緑総合病院

《新潟県》

新潟県立がんセンター新潟病院

労働者健康福祉機構 燕労災病院

上越総合病院

系魚川総合病院

柏崎総合医療センター

新潟県厚生連佐渡総合病院
《山梨県》

山梨病院

市立甲府病院

国民健康保険富士吉田市立病院

《長野県》

昭和伊南総合病院

JA 長野厚生連小諸厚生総合病院

佐久市立国保浅間総合病院

長野県立こども病院

伊那中央病院

まつもと医療センター 松本病院

市立大町総合病院

東 海 地 区

《岐阜県》

岐阜県立下呂温泉病院

医療法人社団誠広会平野総合病院

医療法人社団慈朋会澤田病院

郡上市民病院

岩砂病院・岩砂マタニティ

総合病院中津川市民病院

《静岡県》

財団法人恵愛会聖隷富士病院

共立蒲原総合病院

静岡県立こども病院

ハートセンター磐田

すずかけセントラル病院

のぞみ記念下田循環器・腎臟クリニック

$\mathrm{JA}$ 静岡厚生連 静岡厚生病院

沼津市立病院

《愛知県》

名古屋市立緑市民病院

国立長寿医療研究センター

常滑市民病院

中日病院

名古屋セントラル病院

医療法人宝美会 総合青山病院

総合上飯田第一病院

寿光会中央病院

八千代病院

知多厚生病院

知多市民病院

名古屋市立西部医療センター

成田記念病院

泰玄会病院

三菱名古屋病院

《三重県》

市立伊勢総合病院

尾鷲総合病院

三重県厚生連大台厚生病院

芳野厚生病院

北陸 地区

《富山県》

富山労災病院

《石川県》

石川県済生会金沢病院

芳珠記念病院

公立羽咋病院

金沢赤十字病院

恵寿総合病院

《福井県》

医療法人初生会福井中央クリニック

公立小浜病院

近 畿 地区

《滋賀県》

豊郷病院 
高島市民病院

《京都府》

済生会京都府病院

明治国際医療大学附属病院

医療法人清仁会シミズ病院

医療法人親友会島原病院

洛西二ュータウン病院

医療法人亀岡病院

丹後中央病院

医療法人同仁会 京都九条病院

《大阪府》

大阪府立呼吸器・アレルギー医療センター

松原徳洲会病院

箕面市立病院

近畿大学医学部堺病院

健康保険組合連合会大阪中央病院

医療法人協仁会 小松病院

守口敬任会病院

八尾徳洲会総合病院

市立藤井寺市民病院

医療法人錦秀会 阪和記念病院

第一東和会病院

北大阪けいさつ病院

医療法人生登会 寺元記念病院

西淀病院

山弘会上山病院

友紘会総合病院

茨木医誠会病院

《兵庫県》

国家公務員共済組合連合会六甲病院

一般財団法人甲南会甲南病院

公立豊岡病院 日高医療センター

医療法人回生会宝塚病院

医療法人赤穂中央病院

国立病院機構 兵庫中央病院

兵庫県災害医療センター

真星病院

神戸市立医療センター西市民病院

神戸アドベンチスト病院

西宮市立中央病院

公立神崎総合病院

《奈良県》

大和高田市立病院

恩賜財団済生会御所病院

大和郡山病院

土庫病院

医療法人橿原友紘会 大和橿原病院

《和歌山県》

新宫市立医療センター

中 国地区

《島根県》

国立病院機構 浜田医療センター 益田赤十字病院

《岡山県》

重井医学研究所附属病院

倉敷紀念病院

岡山ハートクリニック

しげい病院

《広島県》

医療法人清幸会 三原城町病院

総合病院庄原赤十字病院

福島生協病院

医療法人社団啓印会村上記念病院

尾道市立市民病院
済生会吳病院

因島医師会病院

高陽ニュータウン病院

国立病院機構 広島西医療センター

せのお循環器科・ 心臟血管外科

脳神経センター大田記念病院

医療法人社団一陽会原田病院

中国中央病院

《山口県》

山口県厚生農業協同組合連長門総合病院

光市立大和総合病院

美祢市立病院

下関市立豊浦病院

周南市立新南陽市民病院

山陽小野田市民病院

医療法人 協愛会 阿知須共立病院

四国地 区

《徳島県》

阿南医師会中央病院

徳島県鳴門病院

阿南共栄病院

田岡病院

医療法人雙立会碩心館病院

《香川県》

四国こどもとおとなの医療センター

高松平和病院

さぬき市民病院

医療法人社団青冥会ミタ二藤田病院

回生病院

《愛媛県》

宇和島社会保険病院

瀬戸内海病院

真泉会 今治第一病院

よつば循環器科クリニック

済生会松山病院

和昌会 貞本病院

HITO 病院

住友別子病院

愛媛県立南宇和病院

医療法人滴水会吉野病院

《高知県》

地域医療機能推進機構 高知西病院

土佐市立土佐市民病院

高知県立あき総合病院

国立病院機構 高知病院

須崎くろしお病院

高知総合リハビリテーション病院

$$
\text { 九 州 地 区 }
$$

《福岡県》

福岡大学筑紫病院

飯塚市立病院

九州労災病院 門司メディカルセンター

地域医療機能推進機構 久留米総合病院

国家公務員共済組合連合会新小倉病院

新行橋病院

社会保険直方病院

中村循環器科心臟外科医院

福岡市民病院

医療法人社団シマダ 嶋田病院

$<ら$ 病院

福岡新水巻病院

草場内科循環器科医院

村上華林堂病院
朝倉医師会病院

小波瀬病院

国立病院機構 大牟田病院

JR 九州病院

宗像医師会病院

大牟田市立病院

医療法人原信会原口病院循環器科内科

《佐賀県》

医療法人春陽会 上村病院

国立病院機構 佐賀病院

新武雄病院

佐賀中部病院

《長崎県》

労働者健康福祉機構 長崎労災病院

医療法人昭和会恵美須町病院

社会医療法人春回会井上病院

長崎県 島原病院

佐世保共済病院

ながさきハートクリニック

五島中央病院

長崎掖済会病院

三佼会宮崎病院

《能本県》

国保水俣市立総合医療センター

熊本市医師会熊本地域医療センター

済生会みすみ病院

熊本再春荘病院

竜山内科リハビリテーション病院

くわみず病院

荒尾市民病院

《大分県》

(社)津久見市医師会立 津久見中央病院

宇佐高田医師会病院

臼杵市医師会立 コスモス病院

新生会 福島病院

国立病院機構 西別府病院

仁泉会畑病院

大分県済生会日田病院

《鹿児島県》

南風病院

垂水市立医療センター垂水中央病院

大隅鹿屋病院

出水郡医師会広域医療センター

国分生協病院

鹿児島県立大島病院

鹿児島県立北薩病院

鹿児島厚生連病院

霧島市立医師会医療センター

医療法人鹿屋ハートセンター

川内市医師会立市民病院

出水総合医療センター

済生会川内病院

医療法人青仁会 池田病院

鹿児島赤十字病院

医療法人浩然会指宿浩然会病院

鹿児島県立薩南病院

《沖縄県》

社会医療法人友愛会 南部病院 沖縄県立宫古病院

医療法人翔南会翔南病院

医療法人和の会与那原中央病院

南部徳洲会病院

沖縄県立八重山病院

沖縄県立北部病院

研修関連施設

なお，研修関連施設一覧は2015年 8 月 1 日現在の情報を元に作成しております

今後名称等に変更が生ずる場合がございますのでご了承願います。また，今後新たに指定・辞退・停止される施設もあり

ますので, 詳細や不明な点につきましては (一社) 日本循環器学会事務局へお問い合わせ下さい.

《専門医担当 : TEL(03) 5501-0864 FAX (03) 5501-9855/e-mail: senmoni@j-circ.or.jp》 


\section{5 年度 専門医研修単位対象学術集会日程（国内）}

\section{会 期}

\begin{tabular}{|c|c|c|}
\hline 会 期 & 学 会 名 & 会 場 \\
\hline 2016/ 3/18(金)- 3/20(日) & $\begin{array}{l}\text { 日本循環器学会学術集会 }(10 \text { 単位 }) \cdot \text { 教育セッ } \\
\text { ション（5 単位）・医療安全（3 単位） } \\
\text { 第80回日本循環器学会学術集会 }\end{array}$ & $\begin{array}{l}\text { 仙台国際センター, 東北大学百 } \\
\text { 周年記念会館 川内萩ホール, } \\
\text { 仙台市民会館, 仙台市新展示施 } \\
\text { 設 (宮城県) }\end{array}$ \\
\hline 2015/9/26(土) & $\begin{array}{l}\text { 日本循環器学会地方会 }(5 \text { 単位 }) \cdot \text { 教育セッショ } \\
\text { ン（3 単位） } \\
\text { 第237回関東甲信越地方会 }\end{array}$ & $\begin{array}{l}\text { 東京ステーションコンファレン } \\
\text { ス (千代田区) }\end{array}$ \\
\hline 2015/10/24 (土) & 第146回東海 - 第131回北陸合同地方会 & $\begin{array}{l}\text { 名古屋ルーセントタワー（名古 } \\
\text { 屋市） }\end{array}$ \\
\hline 2015/11/14 (土) & 第107回四国地方会 & 高知県立県民文化ホール (高知市) \\
\hline 2015/11/28 (土） & 第114回北海道地方会 & 北海道大学学術交流会館 (札幌市) \\
\hline 2015/11/28 (土) & 第120回近畿地方会 & $\begin{array}{l}\text { ナレッジキャピタルコングレコ } \\
\text { ンベンションセンター(大阪市) }\end{array}$ \\
\hline 2015/11/28 (土) & 第122回中国地方会 & アステールプラザ（広島市） \\
\hline 2015/12/ 5(土) & 第238回関東甲信越地方会 & $\begin{array}{l}\text { 東京ステーションコンファレン } \\
\text { ス (千代田区) }\end{array}$ \\
\hline 2015/12/ 5 (土) & 第161回東北地方会 & 仙台国際センター（仙台市） \\
\hline 2015/12/ 5(土) & 第119回九州地方会 & アクロス福岡（福岡市） \\
\hline 2016/ 2/ 6(土) & 第239回関東甲信越地方会 & $\begin{array}{l}\text { 東京ステーションコンファレン } \\
\text { ス（千代田区） }\end{array}$ \\
\hline $\begin{array}{l}2015 / 9 / 18 \text { (金) }-20 \text { (日) } \\
2015 / 10 / 29 \text { (木) }-10 / 31 \text { (土) } \\
2015 / 10 / 17 \text { (土) }-10 / 20 \text { (火) }\end{array}$ & $\begin{array}{l}\text { 循環器関連学会学術集会 (自己申告区分 : } 3 \text { 単位) } \\
\text { 第63回日本心臓病学会学術集会 } \\
\text { 第56回日本脈管学会総会 } \\
\text { 第68回日本胸部外科学会定期学術集会 }\end{array}$ & $\begin{array}{l}\text { パシフィコ横浜（横浜市） } \\
\text { 虎ノ門ヒルズフォーラム (港区) } \\
\text { 神戸ポートピアホテル, 神戸国 } \\
\text { 際展示場 } 1 \text { 号館（神戸市） }\end{array}$ \\
\hline 2015/10/ 9(金)-11(日) & 第38回日本高血圧学会総会 & $\begin{array}{l}\text { 愛媛県県民文化会館（ひめぎん } \\
\text { ホール）（松山市） }\end{array}$ \\
\hline $2015 / 10 / 22$ (木) -24 (土) & 第19回日本心不全学会学術集会 & グランフロント大阪（大阪市） \\
\hline $2015 / 11 / 20$ (金) -21 (土) & 第29回日本冠疾患学会学術集会 & ロイトン札幌（札幌市） \\
\hline 2016/ 1/16(土) - 17 (日) & $\begin{array}{l}\text { 第18回日本成人先天性心疾患学会総会・学 } \\
\text { 術集会 }\end{array}$ & 大阪国際会議場（大阪市） \\
\hline $2016 / 2 / 15$ (月) -17 (水) & 第46回日本心臓血管外科学会学術集会 & 名古屋国際会議場（名古屋市） \\
\hline 2015/11/ 5(木) - 7(土) & $\begin{array}{l}\text { 関連学会学術集会（自己申告区分：1 単位） } \\
\text { 第55回日本核医学会学術総会 }\end{array}$ & $\begin{array}{l}\text { ハイアットリージェンシー東京 } \\
\text { (新宿区) }\end{array}$ \\
\hline 2015/10/31 (土)-11/ 1(日) & 第52回日本臨床生理学会総会 & 大宮ソニックシティ(さいたま市) \\
\hline 2016/ 2/12(金)-14(日) & 第43回日本集中治療医学会学術集会 & $\begin{array}{l}\text { 神戸国際展示場, 神戸国際会議 } \\
\text { 場（神戸市） }\end{array}$ \\
\hline $2016 / 2 / 5$ (金) - 6(土） & 第45回日本心脈管作動物質学会年会 & 阿波観光ホテル（徳島市） \\
\hline
\end{tabular}


この表は2015年 8 月 1 日現在の情報を元に作成しております.今後会期, 会場などの変更が生ずることがございま す. 詳しくは直接学会事務局へお問い合わせください.

地方会の医療安全 DVD セッションについては, 各地方会により開催が異なります．事前に各支部へ必ずご確認をお 願いいたします。

※日本集中治療医学会は2009年 4 月 1 日から関連学会に指定されています。研修単位につきましては第37回日本集中 治療医学会学術集会参加より 1 単位付与となります.

※日本睡眠学会は2010年 4 月 1 日から関連学会に指定されています。研修単位につきましては第35回日本睡眠学会学 術集会参加より 1 単位付与となります.

※日本成人先天性心疾患学会は 2014 年 1 月 17 日から循環器関連学会に指定されています．研修単位につきましては第 17 回日本成人先天性心疾患学会学術集会参加より 3 単位付与となります.

※日本心エコー図学会は2014年 6 月 20 日から関連学会に指定されています。研修単位につきましては第26回日本心工 コー図学会学術集会参加より 1 単位付与となります.

※日本心脈管作動物質学会は2014年10月24日から関連学会に指定されています。研修単位につきましては第45回日本 心脈管作動物質学会年会参加より 1 単位付与となります。

※日本心血管脳卒中学会は2014年10月24日から関連学会に指定されています。研修単位につきましては第 2 回日本心 血管脳卒中学会学術集会参加より 1 単位付与となります.

※日本下肢救済・足病学会は2014年10月 24 日から関連学会に指定されています。研修単位につきましては第 7 回日本 下肢救済・足病学会学術集会参加より 1 単位付与となります. 


\section{5～2016 年＼cjkstart専門医研修単位対象学術集会日程 (海外：2 単位)}

\begin{tabular}{|c|l|l}
\multicolumn{1}{c|}{ 会 期 } & \multicolumn{1}{|c|}{ 学 会 名 } & \multicolumn{1}{|c}{ 開催都市（開催国） } \\
\hline $2015 / 11 / 7$ (土) -11 (水) & AHA Scientific Sessions 2015 & Orlando (U.S.A.) \\
$2016 / 4 / 2$ (土) -4 (月) & ACC Annual Meeting 2016 & Chicago (U.S.A.) \\
$2016 / 8 / 27$ (土) -31 (水) & ESC Congress 2016 & Rome (Italy) \\
\hline
\end{tabular}

○この表は2015年 8 月1日現在の情報を元に作成しております。今後会期，会場などの変更が生ずることがございま す. 詳しくは直接各学会事務局へお問い合わせください. 